\title{
Global Airline Industry's Innovation Efforts After Covid-19
}

Jina Kim and Joosung Lee L* $^{1 *}$

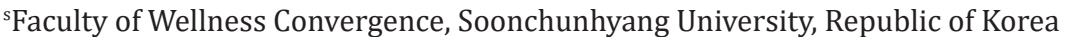

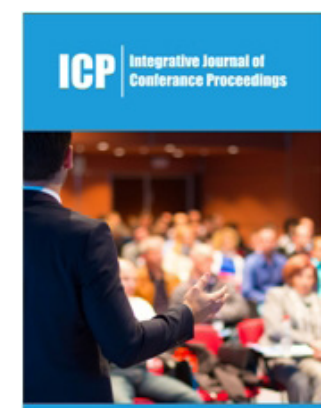

*Corresponding author: Joosung Lee, Faculty of Wellness Convergence, Soonchunhyang University, Republic of Korea

Submission: 诫 November 10, 2020

Published: 悳December 04, 2020

Volume 2 - Issue 4

How to cite this article: Jina Kim and Joosung Lee, Global Airline Industry's Innovation Efforts After Covid-19. Int J Conf Proc. 2(4). ICP. 000541. 2020.

Copyright@ Joosung Lee, This article is distributed under the terms of the Creative Commons Attribution 4.0 International License, which permits unrestricted use and redistribution provided that the original author and source are credited.

\section{Abstract}

This short article examines the impact of COVID-19 on the airline industry and the industry's responses to recover and further innovate its service offerings. Various cases of airline revenue models are discussed via actual measures taken by some of global airlines. This overview can provide insights to revitalize the industry with new business models.

\section{Introduction}

The impact of COVID-19 can be seen on every industry globally. However, amongst all sectors the airline industry has been hit extremely hard by the COVID-19 outbreak-even harder than by the events of $9 / 11$ and the 2008 financial crisis put together. Before the COVID-19 outbreak, the airline industry displayed a steady growth across all countries. According to the report "Economic Performance of the Airline Industry" published by IATA (International Air Transport Association), the projected annual growth of revenue ton-miles (RTM) of 2020 for the international flights by the U.S commercial airlines was roughly four percent. However, in the summer of 2020 the IATA revised its projection, predicting a global loss of US $\$ 84$ billion. Global airline companies are now confronted with the new normal industry dynamics followed by the COVID-19 and are given the task to revitalize their company with new business models.

\section{Impact of Covid-19 on Airline Companies (Commercial Aviation)}

Commercial aviation, both including personal and cargo aviation, showed a minus yearon-year growth ever since January 2020. See the graph below which presents YoY changes of scheduled flight for each country from Jan 2020 to Sep 2020. The most recent data, as of September 2020 the year-on-year change of scheduled flights for each country follows Table 1.

Table 1.

\begin{tabular}{|c|c|}
\hline Country & YoY Change \\
\hline Global & $-48 \%$ \\
\hline Spain & $-61.40 \%$ \\
\hline Hong Kong & $-89.40 \%$ \\
\hline Germany & $-66.40 \%$ \\
\hline Singapore & $-93.50 \%$ \\
\hline Italy & $-58.30 \%$ \\
\hline France & $-55.10 \%$ \\
\hline United Kingdom & $-65 \%$ \\
\hline Australia & $-74.10 \%$ \\
\hline Sweden & $-71.40 \%$ \\
\hline UAE & $-68.70 \%$ \\
\hline South Korea & $-46.40 \%$ \\
\hline United States & $-50 \%$ \\
\hline
\end{tabular}




\section{Changing Consumer (Passenger Travelers) Needs}

As observed above, consumer demands in airline services have declined and such phenomenon is bound to last longer than expected. Not only did airline services' demand fall in general, customer needs have also slightly shifted to a new focus. Historically, the reduction of waiting time and long queues, the efficiency and friendliness of staffs, conveniently made check-in and baggage reclaim were the key success factors for a rich customer experience of airline companies [1-4]. However, these are now stories of the past. After the outburst of COVID-19, consumer demands are no longer those of what conventional airline companies excelled in. The newly open era now challenges and questions various aviation companies of how they could enhance customer experience Figure 1. Then, what could possibly be their new focus?

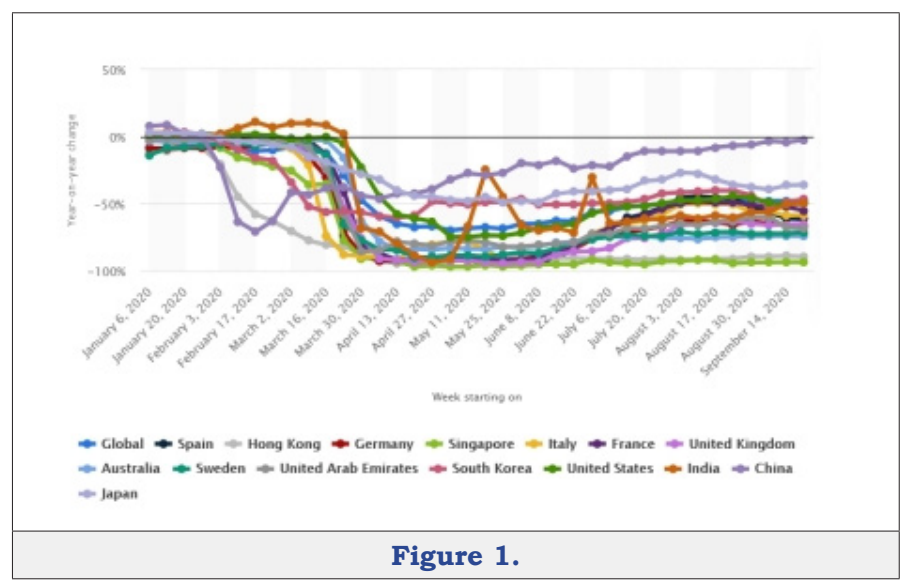

\section{Health and safety}

Owing to the uprising fear of COVID-19, consumers began to demand new measures to ensure health and safety during all stages of air travel. Systematic temperature inspections, reduction of contact between staff and passengers are all examples of the newly desired services.

\section{Frictionless travel experience}

With extra procedures to ensure safety and guarantee COVID-19 free air travel, airline companies may encounter a situation in which they provide even more complex services to their passengers. Accordingly, frictionless travel experience utilizing technologies such as IoT (Internet of Things) will emerge as a critical success factor as well [5-8]. Digitalization will be inevitable. For instance, new technology can be implemented to allow passengers to enable the whole process from check-in to boarding the flight without coming in to contact with another person or a machine.

\section{Alternative travel options}

Owing to lockdowns and restricted international travel, consumers are seeking for alternative travel options that are risk-free of COVID-19. Fulfilling this demand could contribute to boosting the currently declining demand of airline usage. Although not explicitly listed above, there are numerous other pain points and new needs that the customers hold.

\section{Measures Undertaken by Airline Companies}

The most crucial task that airline companies face is to successfully transform their declining revenue trend to a rising one. If a company fails to do so, the sustainability of the company could be at stake. The fact that people are no longer taking flights as they did in the past highlights the importance of airline companies to diversify revenue streams and incorporate other measures, even services to sustain their business. Some of the exemplary innovation cases are presented below $[9,10]$. Whilst some show how each industry players try to combat the COVID-19 situation, many of them resemble the PSS (Product-Service System) which is defined as 'integrated offerings of tangible products, intangible services and the enabling infrastructure providing a productunspecific functional value' (Tietze, 2013).

\section{Singapore airlines}

Singapore Airlines had recently introduced a new travel protocol taking COVID-19 into consideration. They provide all passengers with a safety kit which consists of masks, hand sanitizers, wet tissues, etc. Newspapers, magazines, and even brochures are readily available to passengers via their own mobile application instead of hard copies. Moreover, boarding passes and baggage tags are substituted by QR codes and easily scanned by mobile devices such as the smart phone. In-flight meals are no longer available in short haul flights as well $[11,12]$. This is the most basic approach that an airline can take within the COVID-19 situation-a simple addition of service to their original one.

Another noticeable service was added to Singapore Airlines. Contrary to the traditional role of personal aviation where passengers were moved from one place to another, Singapore airlines settled down on an alternative travel choice. A unique plane ticket for a three-hour ride on the plane with a simple in-flight meal was their solution $[13,14]$. The passengers went nowhere. The only service they were provided was the experience of having a meal while the plane was flying. Nonetheless, the ticket was completely sold within 30 minutes.

\section{Conclusion}

Experts are expecting the devastating effect of COVID-19 to stagnate the demand of the airline industry for a long period of time. Accordingly, airlines are figuring a way to combat such management crisis with a series of innovative measures. They straightforwardly address the changing demands resulted by COVID-19 and seek other services that could serve good to their financials. While some airlines go bankrupt, some are coming up with either relevant or irrelevant development of their services. Whilst the airlines' survival is at stake, a close look into their methods to overcome such a period is needed.

\section{References}

1. https://www.stata.com/statistics/1104036/novel-coronavirus-weekly-flights-change-airlines-region/

2. https://www.bcg.com/publications/2020/post-covid-airline-industry-strategy 
3. https://www.iata.org/en/iata-repository/publications/economic-reports/air-passenger-monthly-analysis---july-2020/

4. https://www.iata.org/en/publications/economics/?EconomicsL1=144\&EconomicsL2=146\#search

5. https://www.oliverwyman.com/our-expertise/insights/2020/mar/ COVID-19-Impact-On-Commercial-Aviation-Maintenance.html

6. https://worldaviationfestivalblog.com/strategies-for-the-post-covid19-future-of-airline-travel-retail-and-fb/

7. https://blog.aci.aero/covid-19-top-10-customer-experience-recommendations-restart-and-recovery-of-airport operations/

8. https://news.klm.com/klm-introduces-cargo-in-cabin-carrying-cargo-on-passenger-seats
9. https://globetrender.com/2020/07/08/innovations-coronavirus-flying-air-travel-safety/

10. https://www.boardofinnovation.com/blog/experiments-pivots-thatkept-emirates-airlines-alive-in-covid-times/

11. h t t p s : / / w w w.donga.com/news / Inter/article / all/20201013/103401293/1

12. h t t p s : / / b i z.ch o s u n. co m / s i te / d a ta / h t m l dir/2020/09/25/2020092501433.html

13. https://www.traveltimes.co.kr/news/articleView.html?idxno=110373

14. https://www.hankyung.com/international/article/202010147457Y

For possible submissions Click below: 